\title{
ANALISA PENGARUH PEMAKAIAN ALAT PENYIRAMAN OTOMATIS BERBASIS MIKROKONTROLER ARDUINO UNO DENGAN SISTEM SPRAY TERHADAP PERTUMBUHAN JAMUR TIRAM
}

\author{
Achmad Umar Khamdani \\ Teknik Mesin, Fakultas Teknik \\ Universitas Maarif Hasyim Latif, Sidoarjo, Indonesia \\ e-mail : ach-umar-khamdani@student.umaha.ac.id
}

\begin{abstract}
ABSTRAK
Perkembangan pembudidaya jamur tiram di indonesia ini mengalami peningkatan, jamur tiram memiliki kandungan gizi yang sangat tinggi tidak sedikit petani jamur yang bercocok tanam di daerah dataran tinggi, jamur tiram bisa tumbuh optimal dengan suhu di bawah $30^{\circ} \mathrm{c}$ dan kelembaban $76 \%-95 \%$ dengan cuaca di indonesia yang berubah ubah petani jamur sering mengalami gagal panen. Perkembangan teknologi sekarang ini semakin canggih bisa memudahkan petani jamur melakukan perawatan budidaya jamur tiram. Dengan cara mengatur suhu dan kelembaban secara otomatis didalam ruangan atau bisa disebut kumbung perkembangan teknologi ini bisa memperkecil kegagalan petani jamur tiram di indonesia. Dalam pembuatan kontrol suhu dan kelembaban otomatis terdapat komponen - komponen yang dibutuhkan yaitu sensor pendeteksi suhu dan kelembaban (dht11) unit penampilan (lcd i2c) dan mikrokontroler (arduino uno) yang kemudian dirangkai menjadi sebuah sistem dan di aplikasikan dengan software. Kondisi kelembaban sangat mempengaruhi terhadap pertumbuhan jamur, setiap 16 jam pertumbuhan jamur bisa mencapai pertumbuhan $2 \mathrm{~cm}$ bahkan hari berikutnya bisa mencapai $4 \mathrm{~cm}$, dan jika tidak menggunakan spray yang menghasilkan kelembaban pertumbuhan jamur $1,5 \mathrm{~cm}$ sampai $2,5 \mathrm{~cm}$. Hasil pengujian berdasarkan gambar 4.8 bahwa alat yang akan digunakan menunjukkan ketika kelembaban menuju kurang dari 76\% maka alat tersebut akan mengaktifkan pompa untuk menyiram area kumbung. Hasil dari penyiraman kumbung ketika kelembaban kurang dari 76\% agar kelembaban dalam kumbung bisa lebih dari 76\%.
\end{abstract}

Kata Kunci : Arduino Uno, Jamur Tiram, Kelembaban, Kumbung, Otomatis, Spray.

\section{PENDAHULUAN}

Jamur tiram memiliki peranan yang cukup penting dalam memenuhi kebutuhan gizi masyarakat yang menggandung 9 asam amino esensial dengan kadar protein yang lebih tinggi (jamur 19-35\%, beras 7,3 \%, gandum 13,2 \% dan susu sapi $25,2 \%$ ) dan pemenuhan kebutuhan ekspor Sampai saat ini tak sedikit juga petani yang telah menanam jamur. Pertumbuhan jamur tiram dapat dilakukan pada daerah iklim dingin sampai daerah tropis. Miselium jamur tumbuh optimal pada suhu $25-30^{\circ} \mathrm{C}$, jamur tiram tumbuh optimal pada suhu $18-20^{\circ} \mathrm{C}$ dan kelembaban sebesar 76\%-96\%. Sehingga dengan iklim di Indonesia yang berubah-ubah dapat mempengaruhi pertumbuhan jamur tiram. Hal ini menyebabkan produksi jamur di Indonesia mengalami penurunan 28,9\% dari tahun 2010 hingga 2016.

Badan kesehatan dunia (FAO) menyatakan bahwa jumlah konsumsi sayuran untuk memenuhi standar kesehatan adalah sebesar 65 kg/kapita/tahun. Dari Kondisi inilah yang menjadikan peluang usaha jamur konsumsi di dalam negeri masih sangat terbuka lebar.

Oleh karena itu, perlu adanya solusi penerapan teknologi tepat guna yang dapat membantu mengoptimalkan tumbuh jamur dengan judul skripsi yaitu "analisa pengaruh pemakaian alat penyiraman otomatis berbasis mikrokontroler arduino uno dengan sistem spray terhadap pertumbuhan jamur tiram" yang di harapkan dapat mengetahui pengaruh waktu kondisi spray pada kumbung jamur dan pertumbuhan jamur bisa lebih cepat.

\section{METODE PENELITIAN}

Perancangan itu terdiri dari kegiatan yang berurutan yaitu identifikasi permasalahan dari kebutuhan masyarakat hingga penyelesaian.

Perancangan adalah awal suatu proses kegiatan dari suatu produk yang dibutuhkan masyarakat untuk membantu usaha dalam kehidupan. Setelah perancangan selesai dilanjutkan dengan pembuatan produk. Berikut ini merupakan serangkaian kegiatan 
yang akan dilakukan dalam sebuah proses perancangan. Kegiatan merancang dilakukan oleh peranang dan pembuatan produk dilakukan oleh pembuat produk. maka penyusunan laporan dilakukan. Adapun diagram alir penelitian ini sebagai berikut:

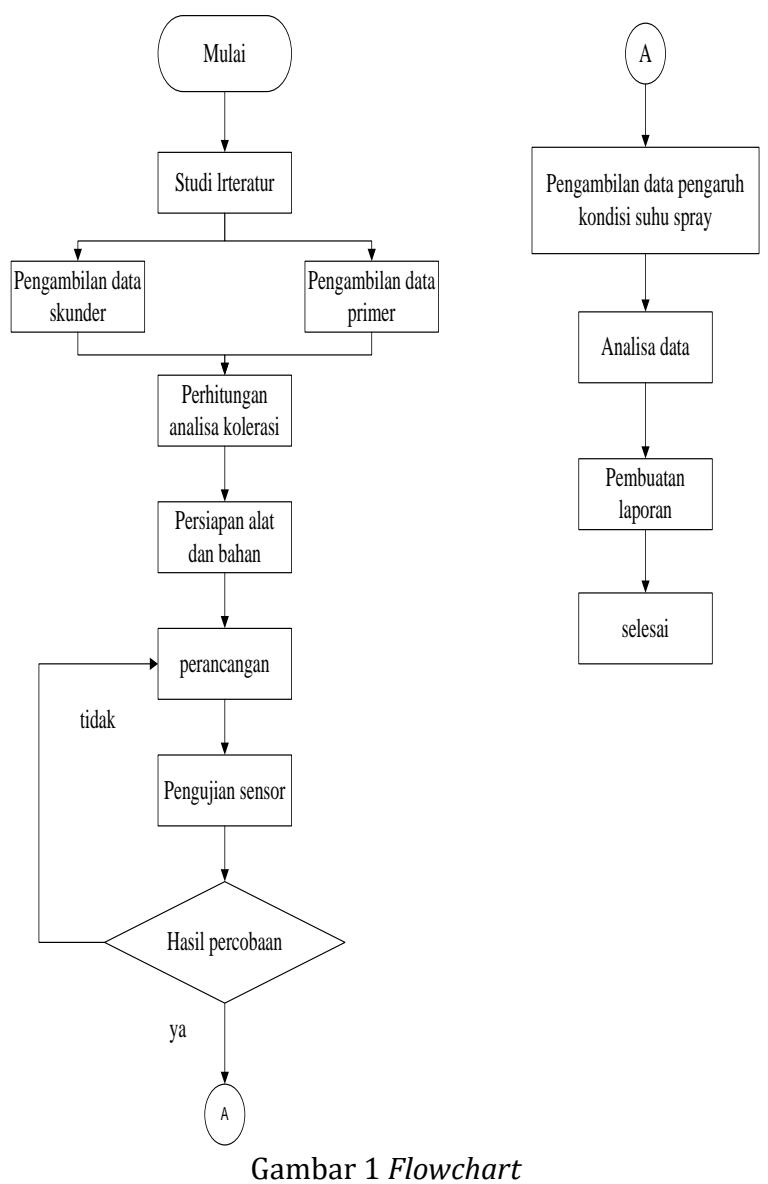

Bahan dan alat

Bahan :
A. Sensor dht11
B. Air
C. Baglog
D. Nozzle
E. Arduino uno
F. Pompa
A. Kabel
B. Selang
C. Tangki air
D. Solder
E. Obeng

Alat - alat :

\section{Waktu Penelitian}

Penelitian dilakukan selama 3 bulan yang dimulai dari perencanaan alat dan penelitian pertumbuhan jamur dengan merancang sebuah kumbung.
Langkah - langkah perancangan dan penelitian

Alur penelitian ini dibuat, maka dilakukan uji sensor sesuai dengan alat ukur yang terkalibrasi. Setelah semua perancangan dan pengujian sensor, maka dilakukan pengujian sistem pada kumbung ketika sistem belum sesuai maka dilakukan perancangan ulang. Pada Hasil percobaan alat berhasil maka dilakukan pengambilan data berupa variabel suhu pada dalam kumbung jamur. Analisa data yang dilakukan pada skripsi ini dengan menghitung nilai kolerasi suhu air dan suhu dalam kumbung adapun penelitian sebagai berikut:

a. Menganalisa suhu dan kelembaban menggunakan alat ukur

b. Menganalisa pertumbuhan jamur tiram menggunakan alat dan tidak menggunakan alat

c. Mengukur lebar spray dan diameter droplet yang dihasilkan dari spray pada alat

d. Menganalisa kolerasi suhu dan kelembaban

e. Pengujian sensor terhadap alat ukur Berikut ini adalah desain Alat sebelum dan sesudah di rancang.

Alat ini berfungsi sebagai pengontrol suhu dan kelembaban secara otomatis, dengan merubah besaran actual menjadi besaran terukur.

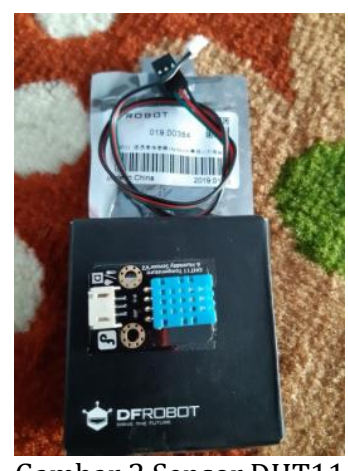

Alat ini berfungsi sebagai pendorong atau yang pemberian aksi tekanan fluida air melalui selang air dan pengkabutan melalui spray splinker

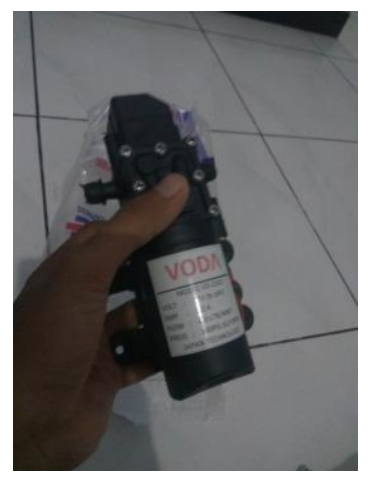

Gambar 3 Pompa Dc/Water

Baglog jamur ini akan menjadi bahan uji, untuk mengetahui pertumbuhan jamur tiram baglog ini 
terbuat dari serbuk kayu dan bekatul dengan campuran lainnya yang dimasukkan kedalam kantong plastik.

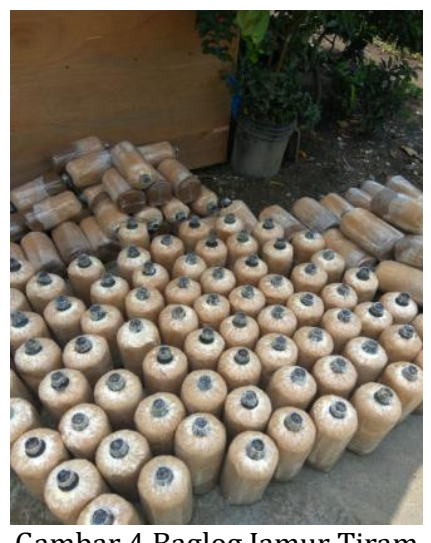

Gambar 4 Baglog Jamur Tiram

Setelah proses persiapan selesai alat dan bahan sudah lengkap dan terkumpul kita rancangdan melakukan penelitian

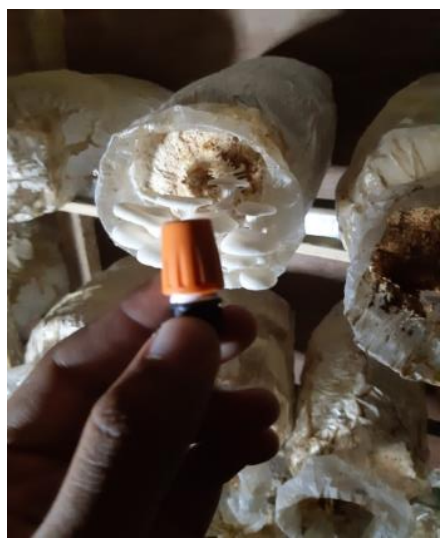

Gambar 5. Spray Splinker

Sensor DHT11 berfungsi sebagai pendeteksi kelembaban, pengontrol on/off pada pompa air, jika kelembaban kurang dari $76 \%$ pompa akan memberi tekanan terhadap air dan melakukan penkabutan melalui sprayer

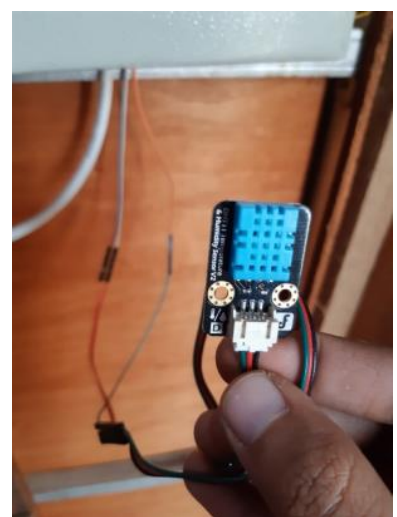

Gambar 6 Sensor Sudah Terpasang

\section{HASIL DAN PEMBAHASAN}

\section{HASIL PENGAMBILAN DATA PRIMER}

Pengambilan data dilakukan pada tanggal 16 juni 2019 berupa variabel kelembaban dan suhu terhadap waktu di dalam kumbung serta di luar kumbung. Berikut merupakan hasil pengambilan data primer hubungan kelembaban terhadap waktu.

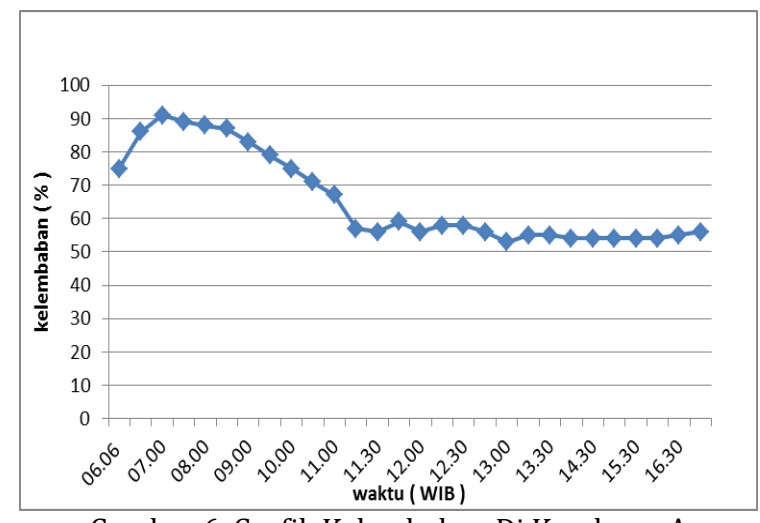

Gambar 6. Grafik Kelembaban Di Kumbung A

Keterangan :

Gambar 6 menunjukkan data hasil pengukuran kelembaban di dalam kumbung A terbesar pada jam 06.00 WIB sampai jam 10.00 WIB. Data pengukuran waktu tersebut pada jam 06.00 WIB. Keadaan lingkungan dalam kumbung menunjukkan tingkat kadar air paling tinggi, ketika menuju jam 10.00 WIB keadaan lingkungan dalam kumbung semakin menurun.

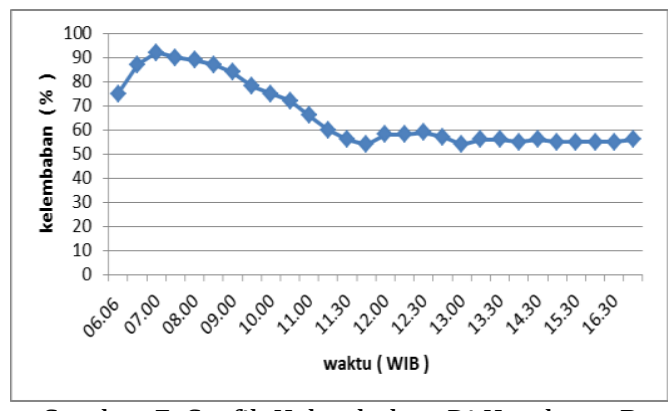

Gambar 7. Grafik Kelembaban Di Kumbung B

Keterangan :

Gambar 7 dari hasil pengukuran kelembaban terbesar di dalam kumbung B terletak pada jam 06.00 WIB sampai dengan jam 10.00 WIB pengukuran data kelembaban Dan waktu tersebut keadaan kumbung A dan kumbung B dengan keadaan yang sama, didalam kumbung tersebut mengalami penurunan kelembabam pada jam $11.00 \mathrm{WIB}$ 


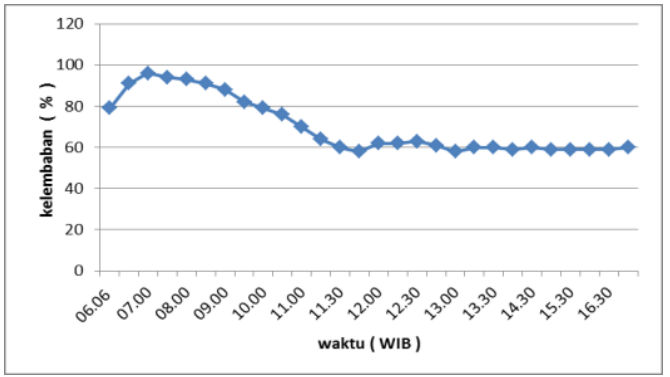

Gambar 8. Grafik Kelembaban Di Luar Kumbung

Keterangan :

Gambar 8 terebut adalah grafik yang menunjukkan kelembaban pada luar atau area sekitar kumbung A dan kumbung B, grafik di atas terlihat titik kelembaban paling puncak pada jam 06.00 WIB dan menurun di saat jam 11.00 WIB.

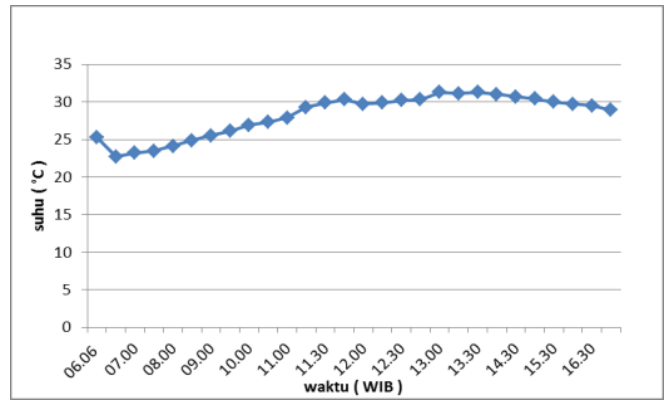

Gambar 9. Grafik Suhu Di Kumbung A

Keterangan :

Gambar 9 ini menunjukkan grafik suhu di dalam kumbung A yang titik paling bawah menunjukkan pada jam 06.00 WIB suhu paling dingin di saat mulai pengukuran dan titik paling atas menunjukkan pada jam $13.00 \mathrm{WIB}$.

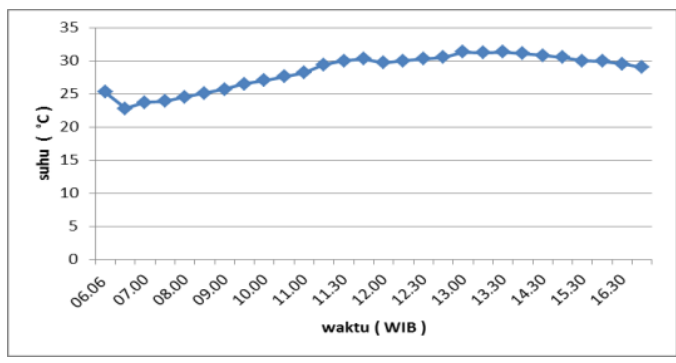

Gambar 10. Grafik Suhu B

Keterangan :

Gambar 10 grafik suhu kumbung B yang menunjukkan bahwa titik paling bawah pada jam 06.00 WIB hampir sama dengan kumbung A dengan titik paling atas dengan temperatur atau suhu pada jam 13.00 WIB.

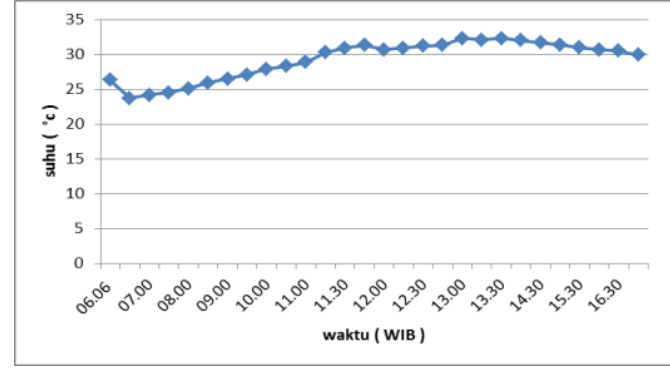

Gambar 11. Grafik Suhu Luar Kumbung

Keterangan :

Gambar 11 ini adalah suhu luar kumbung A dan kumbung B dengan titik puncak pada jam 13.00 WIB dan titik paling rendah pada jam 06.00 WIB di saat titik rendah dan stabil adalah suhu paling bagus.

\section{Hasil Pengambilan Data Sekunder}

Berdasarkan data manual book pompa, tandon air dan selang air data spesifikasi pompa MODEL VD-2203, 12V (9-14V), 3.0 A, 4.0 liter/menit, dengan kapasitas tandon air 55liter, dimensi selang air $4 \times 6 \mathrm{~mm}$ work pres $150 \mathrm{psi}$

\section{Hasil Analisa Kolerasi Suhu Dan Kelembaban}

Pada tahap ini dilakukan pengujian pada hasil pembacaan suhu dan kelembaban yang sudah dikoversi oleh sistem program Arduino. Sensor DHT11 ini mampu mengukur suhu dan kelembaban

Hasil analisa kolerasi suhu dan kelembaban berdasarkan pengambilan data primer di dapatkan grafik hubungan variabel tersebut di tampilkan pada gambar 4.7

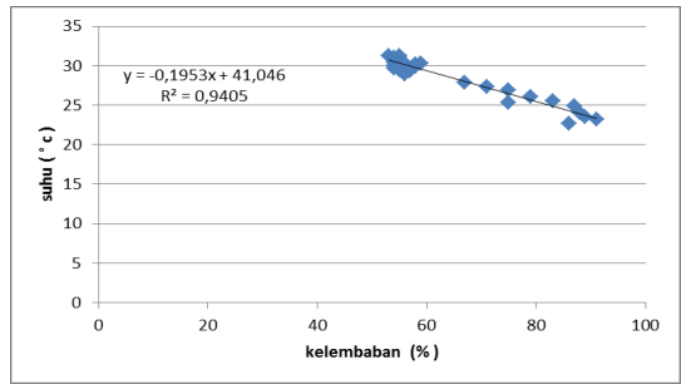

Gambar 12. Grafik Hubungan Variabel Suhu Dan Variabel Kelembaban

Keterangan :

Gambar 12 menunjukkan bahwa terdapat kolerasi antara variabel suhu dan variabel kelembaban yang di tunjukkan dengan hubungan linier. Hal tersebut menunjukkan bahwa perubahan variabel suhu dapat dijelaskan oleh perubahan variabel kelembaban. Hubungan tersebut berdasarkan nilai koefisien kolerasi (r) yang dihasilkan sebesar 0,969. Nilai pada kolerasi 
yang dihasilkan menunjukkan bahwa hubungan variabel suhu dan variabel kelembaban berada pada kategori sangat kuat.

\section{Hasil Pengujian Sensor}

Hasil pengujian sensor kelembaban bertujuan untuk membandingkan nilai keluaran sesnsor dan nilai keluaran alat ukur . nilai yang akan di dapatkan selisih antara hasil sensor dan alat ukur sehingga didapatkan rata - rata error

Tabel 1 Hasil Pengujian Sensor Kelembaban

\begin{tabular}{|c|c|c|c|}
\hline NO & $\begin{array}{c}\text { ALAT } \\
\text { UKUR }\end{array}$ & SENSOR & ERROR (\%) \\
\hline 1 & 90 & 91 & 1,111111 \\
\hline 2 & 80 & 83 & 3,75 \\
\hline 3 & 70 & 71 & 1,428571 \\
\hline 4 & 68 & 65 & 4,411765 \\
\hline 5 & 52 & 55 & 5,769231 \\
\hline
\end{tabular}

Hasil rata - rata error sensor dari tabel 4.1 dapat dihitung menggunakan persamaaan

$$
\begin{aligned}
& \overline{\text { error }}=\frac{\sum \text { error sensor }}{n} \\
& \overline{\text { error }}=\frac{16,470}{5} \\
& \overline{\text { error }}=3,294 \%
\end{aligned}
$$

Hasil perhitungan menunjukkan bahwa sensor yang digunakan dalam alat tersebut sudah sesuai. Hal tersebut di tujukan hasil nilai rata rata error sensor terhadap alat ukur bernilai $3,294 \%$.

\section{Hasil Pengujian Alat}

Hasil pengujian kinerja alat ditujukan pada gambar 4.8

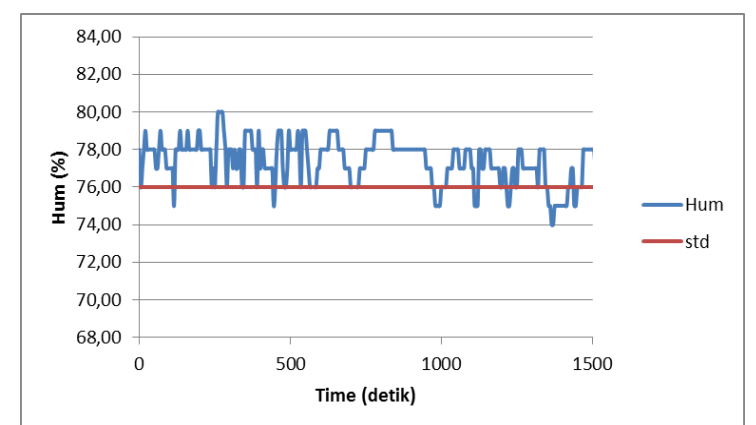

Gambar 13. Grafik Hasil Pengujian Alat

Gambar 13 menunjukkan hasil pengujian alat bahwa alat yang akan digunakan pada kumbung jamur sudah sesuai. Hal tersebut menunjukkan bahwa ketika kelembaban menuju kurang dari $76 \%$ maka alat tersebut akan mengaktifkan pompa untuk menyiram area kumbung. Tujuan dari penyiraman kumbung ketika kelembaban kurang dari 76\% agar kelembaban dalam kumbung bisa lebih dari 76\%.

\section{Pengaruh Kelembaban Pada Kumbung Jamur}

Hasil pengaruh kelembaban pada kumbung jamur menggunakan alat dengan pendeteksi sensor jika kelembaban kurang dari 76\%. Maka spray akan

\begin{tabular}{|c|c|c|c|c|c|c|c|c|c|c|}
\hline \multirow[b]{2}{*}{ no } & \multirow[b]{2}{*}{$\begin{array}{c}\text { hari } \\
\text { ke }\end{array}$} & \multirow[b]{2}{*}{ waktu } & \multirow{2}{*}{$\begin{array}{l}\mathrm{RH} \\
(\%)\end{array}$} & \multirow{2}{*}{$\begin{array}{l}\text { suhu } \\
\left({ }^{\circ} \mathrm{C}\right)\end{array}$} & \multicolumn{2}{|c|}{ baglog 1} & \multicolumn{2}{|c|}{ baglog 2} & \multicolumn{2}{|c|}{ baglog 3} \\
\hline & & & & & $\begin{array}{c}\text { panjang } \\
\mathrm{cm}\end{array}$ & $\begin{array}{c}\text { diameter } \\
\mathrm{cm}\end{array}$ & $\begin{array}{c}\text { panjang } \\
\mathrm{cm}\end{array}$ & $\begin{array}{c}\text { diameter } \\
\mathrm{cm}\end{array}$ & $\begin{array}{c}\text { panjang } \\
\mathrm{cm}\end{array}$ & $\begin{array}{c}\text { diameter } \\
\mathrm{cm}\end{array}$ \\
\hline 1 & & 07.00 & 93 & 23 & 3,5 & 0,5 & 3 & 0,5 & 3,5 & 0,5 \\
\hline 2 & & 11.00 & 81 & 28 & 4,5 & 0,5 & 4,5 & 0,5 & 4 & 0,5 \\
\hline 3 & \multirow{3}{*}{1} & 15.00 & 78 & 28 & 5,5 & 0,5 & 5,5 & 2 & 5,5 & 1,3 \\
\hline 4 & & 19.00 & 80 & 28 & 6 & 1 & 6 & 3 & 6,5 & 2,5 \\
\hline 5 & & 23.00 & 85 & 25 & 6 & 1,5 & 7,5 & 3,5 & 8 & 3,5 \\
\hline 6 & \multirow{5}{*}{2} & 07.00 & 92 & 23 & 7 & 2,5 & 8 & 4 & 9,5 & 5 \\
\hline 7 & & 11.00 & 82 & 29 & 8,5 & 2,5 & 9,3 & 4 & 10 & 6 \\
\hline 8 & & 15.00 & 79 & 28 & 10 & 4 & 9,5 & 5 & 11 & 6,5 \\
\hline 9 & & 19.00 & 82 & 28 & 10 & 5 & 10 & 5,5 & 11,5 & 7 \\
\hline 10 & & 23.00 & 91 & 23 & 10,5 & 6,5 & 10 & 6 & 11,5 & 7 \\
\hline 11 & \multirow{5}{*}{3} & 07.00 & 95 & 22 & 11 & 7 & 10,5 & 7 & 12 & 8 \\
\hline 12 & & 11.00 & 85 & 29 & 11 & 7 & 10,5 & 7,5 & 12 & 8,5 \\
\hline 13 & & 15.00 & 80 & 28 & 11,5 & 7,5 & 10,5 & 7,5 & 12 & 8,5 \\
\hline 14 & & 19.00 & & & & & & & & \\
\hline 15 & & 23.00 & & & & & & & & \\
\hline
\end{tabular}
menyala

Tabel 2. Pertumbuhan Jamur Menggunakan Alat

Tabel 4.2 menunjukkan hasil dari kelembaban dengan pendeteksi sensor $76 \%$. Jika kelembaban kumbung kurang dari $76 \%$ pompa akan menyala dan memberi aksi terhadap spray untuk melembabkan kumbung jamur, pertumbuhan jamur tiram setiap 4 jam sekali bisa tumbuh 1,5 $\mathrm{cm}$ dan jika 1 hari bisa tumbuh $3 \mathrm{~cm}$.

Hasil pertumbuhan jamur tidak menggunakan alat dengan pendeteksi kelembaban melalui alat ukur, pertumbuhan jamur di tunjukkan pada tabel

\begin{tabular}{|c|c|c|c|c|c|c|c|c|c|c|}
\hline & & & & & & Alat & & & & \\
\hline & & & & & & $\log 1$ & & & & $\log 3$ \\
\hline no & $\begin{array}{c}\text { hari } \\
\text { ke }\end{array}$ & waktu & $\begin{array}{l}\mathrm{RH} \\
(\%)\end{array}$ & ( $\left.{ }^{\circ} \mathrm{c} c\right)$ & $\begin{array}{l}\text { panjang } \\
\mathrm{cm}\end{array}$ & $\begin{array}{l}\text { diameter } \\
\mathrm{cm}\end{array}$ & $\begin{array}{l}\text { panjang } \\
\mathrm{cm}\end{array}$ & $\begin{array}{l}\text { diameter } \\
\mathrm{cm}\end{array}$ & $\begin{array}{c}\text { panjang } \\
\mathrm{cm}\end{array}$ & $\begin{array}{l}\text { diameter } \\
\mathrm{cm}\end{array}$ \\
\hline 1 & & 15.00 & 58 & 29 & 2 & 0,5 & 2,5 & 0,5 & 2,5 & 0,5 \\
\hline 2 & 1 & 19.00 & 70 & 27 & 2,5 & 0,5 & 4,5 & 0,5 & 3,5 & 0,5 \\
\hline 3 & & 23.00 & 75 & 26 & 3 & 0,5 & 5 & 0,5 & 4 & 0,5 \\
\hline 4 & & 07.00 & 85 & 24 & 3,5 & 0,5 & 6,5 & 2,5 & 5 & 0,5 \\
\hline 5 & & 11.00 & 57 & 30 & 3,5 & 0,5 & 6,5 & 3,5 & 6 & 1,5 \\
\hline 6 & 2 & 15.00 & 56 & 29 & 4 & 0,5 & 8,5 & 5 & 8 & 2,5 \\
\hline 7 & & 19.00 & 68 & 26 & 4,5 & 0,5 & 10,5 & 5 & 9 & 3 \\
\hline 8 & & 23.00 & 78 & 24 & 5 & 0,5 & 11 & 6,5 & 9,2 & 4,5 \\
\hline 9 & & 07.00 & 83 & 24 & 5,5 & 2 & 11,5 & 7 & 9,5 & 6 \\
\hline 10 & & 11.00 & 55 & 31 & 5,5 & 3 & 11,5 & 7,5 & 9,5 & 7,5 \\
\hline 11 & 3 & 15.00 & 60 & 28 & 7 & 3 & 12,5 & 8 & 11 & 8,5 \\
\hline 12 & & 19.00 & 67 & 27 & 7,8 & 5,5 & 12,7 & 9,5 & 11,2 & 8,5 \\
\hline 13 & & 23.00 & 76 & 24 & 7,8 & 5,5 & 13,3 & 10,4 & 11,2 & 9,2 \\
\hline 14 & & 07.00 & 82 & 23 & 8 & 6 & $13,5 \mathrm{c}$ & 10,5 & 11,5 & 9,5 \\
\hline 15 & & 11.00 & 54 & 29 & 8 & 6 & 13,5 & 11,3 & 11,7 & 9,5 \\
\hline 16 & 4 & 15.00 & & & & & & & & \\
\hline 17 & & 19.00 & & & & & & & & \\
\hline 18 & & 23.00 & & & & & & & & \\
\hline
\end{tabular}
berikut ini :

Tabel 3. Hasil Pertumbuhan Jamur Tidak Menggunakan 
Hasil pertumbuhan jamur tidak menggunakan alat bisa mengetahui kelembaban melalui dari alat ukur thermometer, pertumbuhan jamur tiram dalam 4 jam bisa $0,5 \mathrm{~cm}$ dan jika pertumbuhan jamur tiram dalam 1 hari bisa 1,5 $\mathrm{cm}$.

\section{Hasil Pengaruh Kelembaban Dan Waktu Pada} Kumbung

Hasil pengaruh kelembaban pada kumbung menggunakan alat dengan pendeteksian sensor 1jam sekali dan ketika 1jam tersebut kelembaban menunjukkan nilai kelembaban kurang dari 76\% maka pompa akan menyala selama 15 detik, data di tampilkan pada tabel 4.2

Tabel 4. Hasil Pertumbuhan Jamur Menggunakan Alat 1 Jam 15 Detik

\begin{tabular}{|c|c|c|c|}
\hline no & waktu & kelembaban & pertumbuhan \\
\hline 1 & 07.00 & 91 & \multirow{5}{*}{1,5} \\
\hline 2 & 11.00 & 59 & \\
\hline 3 & 15.00 & 72 & \\
\hline 4 & 19.00 & 87 & \\
\hline 5 & 23.00 & 80 & \\
\hline 6 & 07.00 & 85 & \multirow{5}{*}{3,5} \\
\hline 7 & 11.00 & 50 & \\
\hline 8 & 15.00 & 55 & \\
\hline 9 & 19.00 & 74 & \\
\hline 10 & 23.00 & 82 & \\
\hline 11 & 07.00 & 85 & \multirow{5}{*}{6,5} \\
\hline 12 & 11.00 & 55 & \\
\hline 13 & 15.00 & 58 & \\
\hline 14 & 19.00 & 74 & \\
\hline 15 & 23.00 & 80 & \\
\hline 16 & 07.00 & 83 & \multirow{5}{*}{9} \\
\hline 17 & 11.00 & 55 & \\
\hline 18 & 15.00 & 65 & \\
\hline 19 & 19.00 & 74 & \\
\hline 20 & 23.00 & 82 & \\
\hline
\end{tabular}

Hasil data pada tabel 4.2 menunjukkan selisih pertumbuhan jamur pada hari pertama dan kedua sebesar $2 \mathrm{~cm}$, di hari ketiga selisih pertumbuhan sebesar $4,5 \mathrm{~cm}$, di hari keempat pertumbuhan jamur sebesar $4,5 \mathrm{~cm}$. Data tersebut pada pertumbuhan jamur di pengaruhi oleh kinerja alat, dimana alat akan mengaktifkan pompa ketika kelembaban kurang dari 76\% sehingga dalam kumbung terjadi sistem penyiraman secara otomatis nyala 1 jam 15 detik
Hasil pengaruh kelembaban pada kumbung tidak menggunakan alat dengan perbandingan pada tabel 4.2, data kelembaban tidak menggunakan alat ditampilkan pada tabel 4.3

Tabel 5. Hasil Pertumbuhan Jamur Tidak Menggunakan Alat

\begin{tabular}{|c|c|c|c|}
\hline no & waktu & kelembaban & pertumbuhan \\
\hline 1 & 07.00 & 90 & \multirow{5}{*}{1} \\
\hline 2 & 11.00 & 56 & \\
\hline 3 & 15.00 & 54 & \\
\hline 4 & 19.00 & 66 & \\
\hline 5 & 23.00 & 71 & \\
\hline 6 & 07.00 & 82 & \multirow{5}{*}{2,5} \\
\hline 7 & 11.00 & 52 & \\
\hline 8 & 15.00 & 51 & \\
\hline 9 & 19.00 & 69 & \\
\hline 10 & 23.00 & 76 & \\
\hline 11 & 07.00 & 84 & \multirow{5}{*}{5,5} \\
\hline 12 & 11.00 & 52 & \\
\hline 13 & 15.00 & 52 & \\
\hline 14 & 19.00 & 66 & \\
\hline 15 & 23.00 & 74 & \\
\hline 16 & 07.00 & 80 & \multirow{5}{*}{7} \\
\hline 17 & 11.00 & 52 & \\
\hline 18 & 15.00 & 68 & \\
\hline 19 & 19.00 & 68 & \\
\hline 20 & 23.00 & 76 & \\
\hline
\end{tabular}

Hasil data pada tabel 4.3 menunjukkan selisih pertumbuhan jamur pada hari pertama dan kedua sebesar $1,5 \mathrm{~cm}$, di hari ketiga selisih pertumbuhan sebesar 4,5 cm, di hari keempat pertumbuhan jamur sebesar 2,5 cm. Data tersebut pada pertumbuhan jamur tidak dipengaruhi oleh kinerja alat.

\section{Hasil Pengujian Sudut Dan Panjang Spray Dengan Diameter Lubang Nozzel 0,2 mm}

Hasil data pengujian sudut spray dan panjang spray dengan menggunakan fluida air. Data yang diambil pada pengujian spray tersebut meliputi sudut spray, panjang spray dan droplet dengan menggunakan diameter lubang nozzel 0,2 mm dengan panjang spray $138,11 \mathrm{~mm}$ dan sudut spray $79,77 \mathrm{~mm}$. 


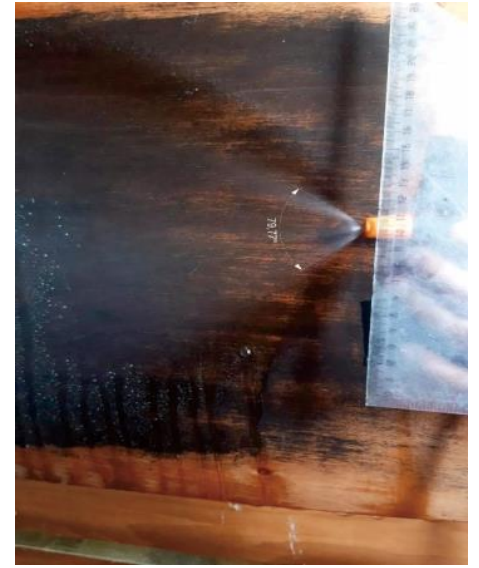

Gambar 14. Sudut Spray Kabut Keterangan :

Hasil dari gambar di atas menunjukkan penyebaran sudut spray sangat berpengaruh terhadap pertumbuhan jamur, semakin lebar sudut spray semakin menyeluruh diarea kumbung jamur dengan sudut spray 79,77 $\mathrm{mm}$ dapat menghasilkan jamur tiram $2 \mathrm{~kg}$ sampai $3 \mathrm{~kg}$ dalam 1 hari.

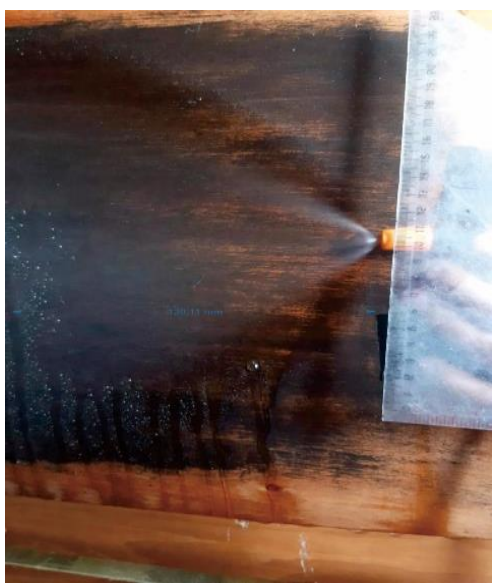

Gambar 15. Panjang Spray Kabut

Keterangan :

Hasil dari data gambar diatas menunjukkan panjang spray sebesar $138,11 \mathrm{~mm}$ yang diambil melalui software imageJ dan corel draw x6.

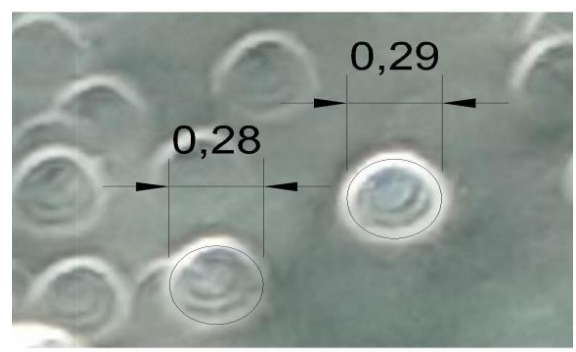

Gambar 16. Droplet Kabut

Keterangan :
Gambar diatas menunjukkan ukuran droplet hasil dari sudut spray dan panjang spray pada gambar 4.7 dan 4.8 dengan diameter sebesar $0,28 \mathrm{~mm}$ dan $0,29 \mathrm{~mm}$.

\section{Pengaruh Kelembaban Pada Kumbung Jamur} Hasil pengaruh kelembaban pada kumbung jamur menggunakan alat dengan pendeteksi sensor jika kelembaban kurang dari 76\%. Maka spray akan menyala.

Tabel 6. Hasil Pertumbuhan Jamur Menggunakan Alat

\begin{tabular}{|c|c|c|c|c|c|c|c|c|c|c|}
\hline \multirow[b]{2}{*}{ no } & \multirow[b]{2}{*}{$\begin{array}{c}\text { hari } \\
\text { ke }\end{array}$} & \multirow[b]{2}{*}{ waktu } & \multirow[b]{2}{*}{$\begin{array}{l}\mathrm{RH} \\
(\%)\end{array}$} & \multirow[b]{2}{*}{$\begin{array}{l}\text { suhu } \\
\left({ }^{\circ} \mathrm{c}\right)\end{array}$} & \multicolumn{2}{|c|}{ baglog 1} & \multicolumn{2}{|c|}{ baglog 2} & \multicolumn{2}{|c|}{ baglog 3} \\
\hline & & & & & $\begin{array}{c}\text { panjang } \\
\mathrm{cm}\end{array}$ & $\begin{array}{c}\text { diameter } \\
\mathrm{cm}\end{array}$ & $\begin{array}{c}\text { panjang } \\
\mathrm{cm}\end{array}$ & $\begin{array}{c}\text { diameter } \\
\mathrm{cm}\end{array}$ & $\begin{array}{c}\text { panjang } \\
\mathrm{cm}\end{array}$ & $\begin{array}{c}\text { diamete } \\
\mathrm{cm}\end{array}$ \\
\hline 1 & \multirow{3}{*}{1} & 15.00 & 78 & 28 & 1,5 & 0,5 & 1 & 0,5 & 1,5 & 0,5 \\
\hline 2 & & 19.00 & 81 & 28 & 2,5 & 0,5 & 2 & 0,5 & 2 & 0,5 \\
\hline 3 & & 23.00 & 94 & 22 & 4,5 & 0,5 & 2,5 & 0,5 & 2,5 & 0,5 \\
\hline 4 & \multirow{5}{*}{2} & 07.00 & 95 & 22 & 5 & 0,5 & 3 & 0,5 & 3 & 0,5 \\
\hline 5 & & 11.00 & 83 & 25 & 6 & 2 & 4,5 & 0,5 & 5 & 0,5 \\
\hline 6 & & 15.00 & 80 & 28 & 8 & 2,5 & 6,5 & 1,5 & 5 & 0,5 \\
\hline 7 & & 19.00 & 79 & 27 & 8,5 & 4 & 7 & 2,5 & 5,5 & 0,5 \\
\hline 8 & & 23.00 & 88 & 23 & 9,5 & 4 & 7,5 & 3 & 6,8 & 0,5 \\
\hline 9 & \multirow{5}{*}{3} & 07.00 & 90 & 23 & 11,5 & 5 & 9 & 5 & 7,5 & 2 \\
\hline 10 & & 11.00 & 80 & 27 & 13 & 6,5 & 10,3 & 6 & 9,5 & 3,3 \\
\hline 11 & & 15.00 & 78 & 28 & 14 & 8 & 10,5 & 7,5 & 11 & 5 \\
\hline 12 & & 19.00 & 78 & 26 & 15 & 9,5 & 12 & 8,5 & 11,5 & 5,5 \\
\hline 13 & & 23.00 & 82 & 23 & 17 & 11,5 & 14 & 11 & 13,5 & 6,5 \\
\hline 14 & \multirow{5}{*}{4} & 07.00 & 90 & 23 & 20 & 14 & 15 & 13,5 & 14,2 & 8,2 \\
\hline 15 & & 11.00 & 80 & 28 & 21 & 15 & 15,5 & 14 & 14,5 & 9 \\
\hline 16 & & 15.00 & 79 & 28 & 21,5 & 15,5 & 16 & 14,5 & 16 & 9 \\
\hline 17 & & 19.00 & 80 & 28 & 22,5 & 18,5 & 17 & 16,5 & 16 & 11 \\
\hline 18 & & 23.00 & 94 & 23 & 23 & 19 & 17 & 16,5 & 16,5 & 11 \\
\hline 19 & \multirow{2}{*}{5} & 07.00 & 94 & 23 & 23,5 & 19 & 17,5 & 16,5 & 16,5 & 11 \\
\hline 20 & & 11.00 & 80 & 28 & 23,5 & 19 & 18 & 16,5 & 17,5 & 11 \\
\hline
\end{tabular}

Hasil dari kelembaban dengan pendeteksi sensor 76\%. Jika kelembaban kumbung kurang dari 76\% pmpa akan menyala dan memberi aksi terhadap spray untuk melembabkan kumbung jamur, pertumbuhan jamur tiram setiap 4 jam sekali bisa tumbuh $2 \mathrm{~cm}$ dan jika 1 hari bisa tumbuh $4 \mathrm{~cm}$.

Hasil pertumbuhan jamur tidak menggunakan alat dengan pendeteksi kelembaban melalui alat ukur, pertumbuhan jamur di tunjukkan pada tabel berikut ini :

Tabel 7. Hasil Pertumbuhan Jamur Tidak Menggunakan Alat

\begin{tabular}{|c|c|c|c|c|c|c|c|c|c|c|}
\hline \multirow[b]{2}{*}{ no } & \multirow[b]{2}{*}{$\begin{array}{c}\text { hari } \\
\text { ke }\end{array}$} & \multirow[b]{2}{*}{ wakts } & \multirow[b]{2}{*}{$\begin{array}{l}\mathrm{RH} \\
(\%)\end{array}$} & \multirow[b]{2}{*}{$\begin{array}{l}\text { suhu } \\
\left({ }^{\circ} \mathrm{c}\right)\end{array}$} & \multicolumn{2}{|c|}{ baglog 1} & \multicolumn{2}{|c|}{ baglog 2} & \multicolumn{2}{|c|}{ baglog 3} \\
\hline & & & & & $\underset{\mathrm{cm}}{\text { panjang }}$ & $\underset{\mathrm{cm}}{\text { diameter }}$ & $\begin{array}{c}\text { panjang } \\
\mathrm{cm}\end{array}$ & $\begin{array}{c}\text { diameter } \\
\mathrm{cm}\end{array}$ & $\begin{array}{c}\text { panjang } \\
\mathrm{cm}\end{array}$ & $\begin{array}{c}\text { diameter } \\
\mathrm{cm}\end{array}$ \\
\hline 1 & \multirow{3}{*}{1} & 15.00 & 60 & 28 & 1,5 & 0,5 & 1 & 0,5 & 2 & 0,5 \\
\hline 2 & & 19.00 & 67 & 27 & 2 & 0,5 & 1,5 & 0,5 & 3 & 0,5 \\
\hline 3 & & 23.00 & 70 & 24 & 2,5 & 0,5 & 2 & 0,5 & 4,5 & 0,5 \\
\hline 4 & \multirow{5}{*}{2} & 07.00 & 82 & 23 & 3 & 0,5 & 2,5 & 0,5 & 6 & 0,5 \\
\hline 5 & & 11.00 & 54 & 29 & 4 & 0,5 & 3,5 & 0,5 & 7 & 1 \\
\hline 6 & & 15.00 & 50 & 30 & 4,5 & 0,5 & 4,5 & 0,5 & 7,8 & 1,3 \\
\hline 7 & & 19.00 & 64 & 26 & 6 & 0,5 & 5 & 0,5 & 8 & 1,5 \\
\hline 8 & & 23.00 & 70 & 24 & 6,5 & 1 & 6,2 & 0,5 & 10,2 & 2,2 \\
\hline 9 & \multirow{5}{*}{3} & 07.00 & 80 & 23 & 7,9 & 1,9 & 6,5 & 1,4 & 12 & 3,5 \\
\hline 10 & & 11.00 & 50 & 31 & 8,5 & 2,5 & 7,2 & 1,7 & 12,2 & 5 \\
\hline 11 & & 15.00 & 50 & 30 & 9,7 & 3,5 & 8 & 2 & 13 & 5,5 \\
\hline 12 & & 19.00 & 65 & 27 & 12,5 & 5,5 & 9,5 & 2,7 & 14 & 6 \\
\hline 13 & & 23.00 & 70 & 24 & 14,5 & 7 & 10,5 & 4 & 15,5 & 7,5 \\
\hline 14 & \multirow{5}{*}{4} & 07.00 & 83 & 25 & 14,5 & 7 & 12,5 & 5,5 & 16 & 9 \\
\hline 15 & & 11.00 & 48 & 30 & 15 & 7,5 & 13 & 7 & 17,5 & 9,5 \\
\hline 16 & & 15.00 & 50 & 30 & 16,5 & 8 & 14 & 8 & 18,5 & 10 \\
\hline 17 & & 19.00 & 65 & 28 & 18 & 10 & 15,5 & 9,5 & 19 & 10 \\
\hline 18 & & 23.00 & 71 & 24 & 20 & 12,5 & 16 & 10 & 19,5 & 10,5 \\
\hline 19 & \multirow{4}{*}{5} & 07.00 & 80 & 25 & 21 & 12,5 & 17 & 10,5 & 20 & 10,5 \\
\hline 20 & & 11.00 & 50 & 30 & 21,5 & 13 & 17,5 & 11,3 & 21 & 11 \\
\hline 21 & & 15.00 & 55 & 28 & 21,5 & 13 & 18 & 11,5 & 21,5 & 11 \\
\hline 22 & & 19.00 & 69 & 26 & 21,5 & 13 & 19 & 12 & 21,5 & 11 \\
\hline
\end{tabular}

Pertumbuhan jamur tidak menggunakan alat bisa mengetahui kelembaban melalui dari alat ukur thermometer, pertumbuhan jamur tiram dalam 4 
jam bisa $1 \mathrm{~cm}$ dan jika pertumbuhan jamur tiram dalam 1 hari bisa $2,5 \mathrm{~cm}$.

\section{Hasil Pengujian Sudut Dan Panjang Spray}

Data yang diambil pada pengujian spray tersebut meliputi sudut spray, panjang spray dan droplet dengan sudut spray $31,42 \mathrm{~mm}$, panjang spray 140,70 mm dengan butiran droplet $1 \mathrm{~mm}$, dari hasil pengujian spray ini meliputi pertumbuhan jamur pada tabel 4.6

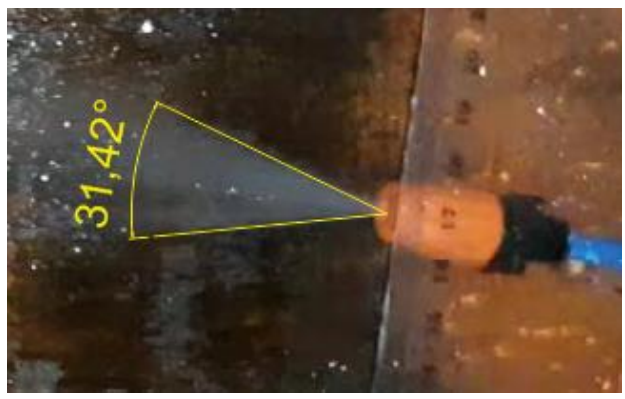

Keterangan :

Gambar 17. Sudut Spray Panjang

Hasil pengujian sudut spray terdapat sudut dengan $31,42^{\circ}$ dengan menghasilkan pertumbuhan jamur pada gambar 4.6

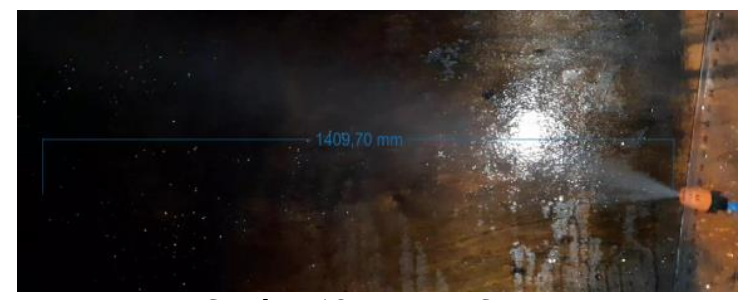

Gambar 18. Panjang Spray

Keterangan :

Hasil pengujian panjang spray splinker terdapat panjang $140,70 \mathrm{~mm}$.

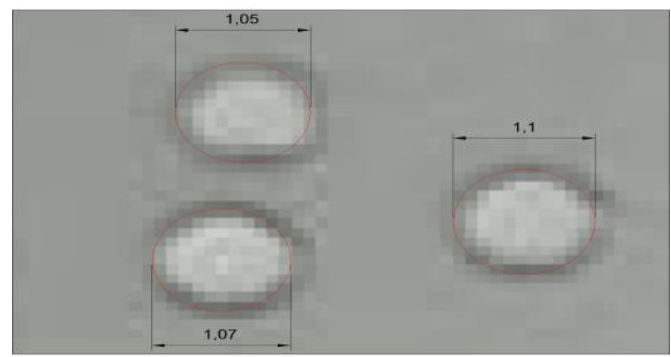

Gambar 19. Droplet

Keterangan :

Butiran droplet diatas menunjukkan hasil dari sudut dan panjang spray dari gambar 4.10 dan 4.11 dengan menunjukkan diameter droplet 1,06 $\mathrm{mm}$ dan 1,07 $\mathrm{mm}$.

\section{PENUTUP}

Dari hasil analisa dapat disimpulkan bahwa pengaruh pertumbuhan jamur tiram jika menggunakan alat, panen jamur bisa 2 setengah hari sampai 3 hari dan jika pertumbuhan jamur tidak menggunakan alat, panen jamur bisa mencapai 4 hari sampai 5 hari.

Sistem monitoring yang bisa diaplikasikan menggunakan sensor DHT11, dimana sinyal dari sensor akan dikirim ke mikrokontroler arduino uno sehingga layar LCD bisa menampilkan sebuah variabel kelembaban

Kelembaban sangat berpengaruh terhadap pertumbuhan jamur berdasarkan perbandingan tabel 4.2 dan 4.3, setiap 16 jam pertumbuhan jamur saat menggunakan alat bisa mencapai pertumbuhan $2 \mathrm{~cm}$ bahkan hari berikutnya bisa mencapai $4 \mathrm{~cm}$, dan jika tidak menggunakan alat atau manual yang menghasilkan kelembaban pertumbuhan jamur 1,5 cm sampai 2,5 cm

Hasil pengujian berdasarkan gambar 4.8 bahwa alat yang akan digunakan menunjukkan ketika kelembaban menuju kurang dari $76 \%$ maka alat tersebut akan mengaktifkan pompa untuk menyiram area kumbung. Hasil dari penyiraman kumbung ketika kelembaban kurang dari $76 \%$ agar kelembaban dalam kumbung bisa lebih dari $76 \%$.

\section{UCAPAN TERIMA KASIH}

Ucapan terima kasih kepada seluruh Dosen Umaha, Khususnya Dosen Teknik Mesin ( Bapak Ir. Subagyo MT ) atas bimbingan dan saran diberikan sehingga Saya dapat menyelesaikan penelitian ini tepat waktu. Serta teman - teman dan keluarga atas dukungannya

\section{DAFTAR PUSTAKA}

Ade Barlian Tandiono, Moch. Rusli, \& Muhammad Aziz Muslim. (2016). Pengendalian Suhu dan Kelembaban pada Budidaya Jamur Tiram dengan Menggunakan Metode Kontrol Logika Fuzzy. Jurnal EECCIS (Electrics, Electronics, Communications, Controls, Informatics, Systems), 10(1), 1619. Retrievedfrom http://jurnaleeccis.ub.ac.id/index.php/ee ccis/article/view/478/303

Afifah, Y. N. (2016). Aliran Tak Tunak Fluida Nano Magnetohidrodinamik (MHD) Yang Melewati Bola Teriris.

Afifah, Y. N. (2019). (2019). Analysis of Unsteady Magneto Hydro Dynamic ( MHD ) Nano Fluid Flow Past A Sliced Sphere Analysis of Unsteady Magneto Hydro Dynamic ( 
MHD ) Nano Fluid Flow Past A Sliced Sphere. IOP Conference Series: Materials Science and Engineering, 494, 012033. https://doi.org/10.1088/1757899X/494/1/012033

Afifah, Y. N., \& Putra, B. C. (2018). Model Matematika Aliran Tak Tunak Pada Nano Fluid Melewati Bola Teriris Dengan Pengaruh Medan Magnet. Teknika: Engineering and Sains Journal, 2(2), 119124.

Alfianto, E. (2016). Rancang Bangun Rumah Budidaya Burung Walet dengan Sistem Pengendalian Suhu Otomatis Sederhana Menggunakan Arduino UNO. ENARODROID, 2(1).

https://doi.org/10.31090/narodroid.v2i1. 206

Anggi Triyanto, N. (2016). Pengatur Suhu dan Kelembapan Otomatis Pada Budidaya Jamur Tiram Menggunakan Mikrokontroler ATMega16. Tesla, 18(1), 25-36.

asep sunandar, bambang sumarsono, agung witjoro, A. husna. (2012). Laporan Akhir Program IPTEKS bagi masyarakat.

Hadi, S., \& Rakhmad, F. (2015). Pengatur Suhu dan Kelembaban pada Miniatur Kumbung Jamur Tiram. In

Http://Repository.Its.Ac.Id. Retrieved from http://repository.its.ac.id/41614/

ikhsan parinduri, helmi fauzi siregar, I. (2017). Pembuatan alat pengontrol suhu dan kelembaban kumbung jamur tiram putih. Teknik

Kurniawan, D., Budiana, E., Deendarlianto, \& Indarto. (2017). Simulasi Numerik Fenomena Single Droplet Menggunakan Metode Volume Hingga dan FrontTracking. Poros, 15(2), 84-91.

Mahajan, P. V., Oliveira, F. A. R., \& Macedo, I. (2008). Effect of temperature and humidity on the transpiration rate of the whole mushrooms. Journal of Food Engineering, 84(2), 281-288. https://doi.org/10.1016/j.jfoodeng.2007. 05.021

Puji, T. (2017). Perancangan dan Pembuatan Kontrol Monitoring Suhu Secara Otomatis dalam Budidaya Jamur Tiram Berbasis Arduino Uno.

Qomarudin, M. H., Metyana, A. C., \& Afifah, Y. N. (2020). Analisis Kestabilan dan Travelling Wave pada Model Penyebaran Virus Ebola. Briliant: Jurnal Riset Dan Konseptual, $\quad 5(2), \quad 369$. https://doi.org/10.28926/briliant.v5i2.44
1

Suharjanto. (2014). Rancang Bangun Otomatisasi Intensitas Cahaya. Fakultas Teknik Program Studi Teknik Elektro, (25020986), 1-6.

Sulistyo, A. D. A., Wirawan, I. K. G., \& Ghurri, A. (2017). Uji Karakteristik Distribusi Butiran Minyak Kelapa Pada Semburan Nosel Burner Sederhana. Jurnal METTEK, 3(1), 29-35.

Wiranata, A. (2015). Studi Visualisasi Dinamika Tumbukan Multiple Droplet Pada Permukaan Stainless Steel Bersuhu Tinggi Dengan Bilangan Weber Rendah. 1-4.

Yunita Nur Afifah, MNH Qomarudin, \& Imamatul Ummah. (2020). Optimal Control Model Pemanenan Prey-Predator di Area Konservasi Ikan. Buana Matematika: Jurnal Ilmiah Matematika Dan Pendidikan Matematika, 10(1), 1-16. https://doi.org/10.36456/buanamatemat ika.v10i1.2410 